\title{
REMARKS ON CHRISTOPHOR FÜRECKER'S STUDIES AT LEIDEN UNIVERSITY AND THE DATE OF HIS BIRTH
}

\author{
Ernesta KAZAKĖNAITE் \\ Vilnius University
}

1. There are very few pieces of biographical information about Christophor Fürecker (lat. Christophorus Fureccerus ${ }^{1}$ ). Currently, we know of a small number of precise references to him in documents of the $17^{\text {th }}$ century. These are ${ }^{2}$ : 1) on $1^{\text {st }}$ of May 1632 in Academia Gustaviana (now the University of Tartu) he is referred on the Depositio ${ }^{3}$ list as „Christophorus Fureccerus, Semgallus“, and on the $15^{\text {th }}$ of May 1632 he was enrolled as „Christophorus Fureccerus, Nersta-Semgallus“ (see Recke, Napiersky 1859:204; Bērziņš 1928: 150; Tering 1984: 138; 2018: 317);

2) on $10^{\text {th }}$ June $^{4} 1633$ and $12^{\text {th }}$ August he participated in the Academia Gustaviana disputes, led by Georg Mancelius (see Sainio 1978: 39-40; Tering 1984: 138);

$3)$ on $6^{\text {th }}$ October 1636 he enrolled at Leiden University (see below);

4) on $23^{\text {rd }}$ February $1644^{5}$ he visited Sebastian Besser at Pienava Manor ${ }^{6}$ (see Arbuzov 1890: 36);

5) in 1677 he is mentioned as the godfather of the son of Martin Büchner, pastor of Engure (see Arbuzovs 1925: 107; Bērziņš 1928: 156).

Other biographical references to Fürecker lead to mere speculation as to how things may have been. For example, one can suppose that Fürecker studied at a gymnasium in the town of Tartu, and although this seems to be an undeniable fact ${ }^{7}$, it is not known exactly from when: in one place, it is stated that he

1 Also Christoph Fürecker (Recke, Napiersky 1859: 204; Tering 2018: 317) and Christophorus Furexerus (see the entry from Leiden University further on). Sainio (1978:40, 113) mistakenly referred to him as Christianus Fureccerus, since in disputes he was referred to three times written as Christophorus Fureccerus (see Mancelius 1633: [8], [25], [61]).

2 The dates are based on the old calendar, i.e the ones noted in the entry or the ones indicated by the authors.

3 The deposition (from Latin depositio cornuum „taking off the horns“) is the ceremonial discarding of immaturity by the newly registered student (Rüegg 1992: 349).

4 In Grudule (2015: 8; 2017: 116) and Tering (2018:317) mistakenly written the $17^{\text {th }}$ June (see Mancelius 1633: [25]).

5 LKV (5: 8679) showed that he visited in 1643, but according to Arbuzov (1890: 36) Besser only arrived in Pienava in the February of 1644.

6 It is interesting that Michael Sartorius visited Besser in 1642, who, like Fürecker, also studied theology in Leiden in 1636 (registered on $2^{\text {nd }} J u l y$ ) (see Arbuzov 1890: 35).

7 This could indeed have happened, since in late 1630 a gymnasium was opened in Tartu. In 1632 it was reorganized into a university (Frijhoff 2008: 177), and $62.2 \%$ of the first 45 students came from the gymnasium. The rest were from Uppsala University $(21.4 \%)$ and elsewhere (Tering 1984: 138). 
started in 1630 (Draviņš 1965: 98, 112), yet elsewhere, in 1631 (Tering 1984: 138). There is a similar situation concerning Fürecker's time in Dobele (in the cultural region Zemgale in Latvia), which we know of from Heinricus Adolphi's foreword in the 1685 edition of Vermehretes Lettisches Hand=Buch and thanks to the historian Tetsch (1770: 172-73). Similarly, the most important dates - of his birth and of his death - are also just hypotheses in references and are indeed not all correct (see below 2). In Adolphi's aforementioned foreword in the 1685 edition of VLH, we find out that Fürecker was already dead by then. The foreword was signed in the spring therefore references can be found from the year 1684 and more often from 1685, but in most cases, it is around 1685 or $1684 / 1685$. The birth dates in references are even more varied due to the lack of knowledge, but since relatively new information about Fürecker's study period in Leiden came to light the facts have become clearer.

2. Thanks to the correspondence between Māra Grudule and Jürgen Beyer ${ }^{8}$, a new focus can be placed on Fürecker's studies at Leiden University, previously unknown to researchers working on him. It seems that the first mention of these studies is in the book Album Academicum der Universität Dorpat (Tartu), 1632-1710 (1984), published by Arvo Tering, in which we read:

\section{Mai}

38. Fürecker (Füreckerus, Fürexer), Christophor(us), Nerft (Semg). * um 1612, lebte noch 1677, † vor 1685. V.: Chr. F., P. in Nerft. Stud. Gymn. Dorpat 1631, imm. Leiden ${ }^{2}$ 6. 10. 1636 (Theol.). AG: Dep. 1. 5. 1632; Disp. 10. 6. 1633, 12. 8. 1633 (Mancelius). Lebte in Kurland wahrsch. als Präzeptor; Verfasser d. lett. Grammatik, lett. geistlicher Dichter, Ubersetzer d. Bibel ins Lettische.

Lit.: L. Bērzinš. Kristofors Fürekers un viña nõzime, 145-224; L. Bērzinš. Kristofors Fürekers, 362-365; K. Dravinš, Kristofora Fürekera jaunïbas dzejoli. 124-126; K. Dravinక. Altlettische Schriften, 60-67, 83-114; K. Dravinš. Zwei Beiträge, 88-90; A. Ozols. Veclatviešu rakstu valoda, 211-229; Busch, 417; Alb. stud. Acad. Lugd., 281; Sainio, 39, 40.

Qu.: UB Tartu, F. 7, Nr. 32, Bl. 3v.; Nr. 33, Bl. 3.

(Tering 1984: 138)

Although it is stated in the latter and in other books (Tering 2008: 303) that Fürecker is "the translator of the Bible into Latvian“, this could be contested as he translated only parts of the Bible. Overall however, Tering provides a lot of important information regarding the facts. In addition to

8 See Grudule 2015: 8, footnote 5 or 2017: 116, footnote 7. 
the aforementioned, we can notice relatively new information which is lacking in the literature in Latvian - Fürecker was born around 1612. So far, only the following possibilities can be found in references: 1613/15 (see Ozols 1965: 211) and around 1615 (see Grudule 2015: 8; 2017: 116). Thus, although Bērziņš, among others, assumed that Fürecker entered university at the age of 20 exactly, ${ }^{9}$ the date 1612 cannot be found anywhere else. When I began to take more of an interest in Fürecker's studies in Leiden, I found a list of the students of Leiden University, printed in the book Album studiosorum Academiae lugduno batavae MDLXXV-MDCCCLXX (1875), where we can read on page 281:

\section{Oct. 6. Johasnes Rota Rotterollamensis. 20, P. Jacobus Wacrius Medioburgensis. 20, T. Jacobis Sluyskf.s Haidervicenus. 26, J. n Curistophorus Furexfrus Semgallus. 24. T.}

(Album studiosorum 1875: 281)

The inscription dated $6^{\text {th }}$ October 1636 is important not only because it shows that Fürecker studied theology (T.) in Leiden, but also that he was 24 years old at that time. This means that the year of his birth should be $\mathbf{1 6 1 2}$ rather than $1615 .{ }^{10}$ Most likely, according to the record from Leiden University, Tering also indicated this date.

The aforementioned Album studiosorum Academiae lugduno batavae $M D L X X V-M D C C C L X X(1875)$ does not show how long Fürecker's studies lasted, but Tering (2018: 317) suggests that it was until 1638 and adds that he had to receive a scholarship from the Lutheran church. ${ }^{11}$ Reviewing the lists

9 Although the most detailed study about Fürecker was written by Bērziņš (1928), his birthday is neither given nor discussed at any point in the paper, apart from on page 154: „Rēkininot, ka viņš̌ universitātē iestājas ar apaliiem 20 gadiem, vinam tobrīd, kad Adolfijs nonāca Dobelē, būtu jau bijis gadu 40.“ („Considering that he started university at precisely 20 years of age, he would have been 40 at the time Adolphi arrived in Dobele.") [highlighted by E. K.].

${ }_{10}$ Of course, if Fürecker's date of birth had been after $6^{\text {th }}$ October, one could think that he was born in 1611, since he would have been 24 at that time. However, the record was made at the end of the year, on the $6^{\text {th }}$ of October, which is why it is more accurate to state that his date of birth would have been 1612. But, for example, has it been halfway through the year, it could have been otherwise, like for example Lithuanian Jonas Božimovskis, who was registered on $15^{\text {th }}$ July 1636 . It states that he was 25 years old (Album studiosorum 1875:278), and this is correct, because it is known that he was born on $11^{\text {th }}$ October 1610.

${ }^{11}$ Indeed, according to Leiden University's librarian Silvia Compaan-Vermetten, although Tering (2018: 17) referred to the „Spendenbuch Leiden“ to claim that Fürecker had studied until 1638 , he is not mentioned in it. This information must still be verified de visu. 
of students of Leiden University, Martine Zoeteman-van Pelt (2011: 421) notes that university members had to renew their registration annually in February, the so-called „recensie“. For this reason, we could hope to find the exact date that Fürecker finished his studies, or at least a year where he would be absent from the lists. Unfortunately, after collaborating with the librarian Silvia Compaan-Vermetten from the Special Collections Services of Leiden University, it turned out that the 'recensielijsten' for the period 1622-1650 have not been preserved ${ }^{12}$. Therefore, at this point, it remains unclear as to how long Fürecker's studies in Leiden lasted.

In reality, the printed Album studiosorum Academiae lugduno batavae MDLXXV-MDCCCLXX (1875) does not contain all the information regarding the register : the place of residence is not included. With the help of the librarian Silvia Compaan-Vermetten I was able to find and order the full record of Fürecker's registration, which is the following ${ }^{13}$ :

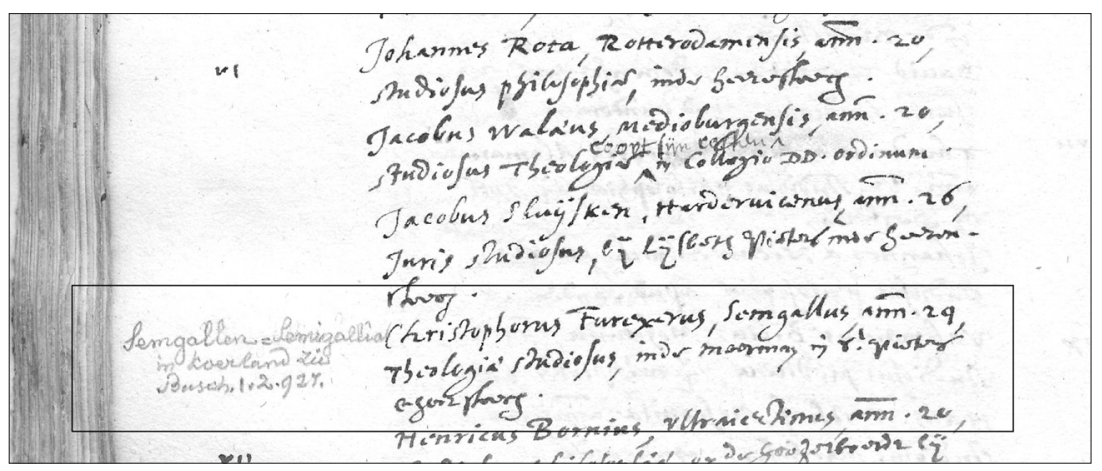

(Copy of the original Album studiosorum p. 162 from the Leiden University archive; shelf mark ASF 9)

Christophorus Furexerus, Semgallus, ann. 24, Theologia studiosus, in de Moorman in S. Pieters choorsteech.

12 For more, see Prögler 2016: 130.

13 The writing in pencil on the left hand side was made later, possibly whilst preparing the Album studiosorum Academiae lugduno batavae MDLXXV-MDCCCLXX (1875) or maybe even later. It was most likely needed because there was only one student with the remark „Semgallus“ in the history of Leiden University. 


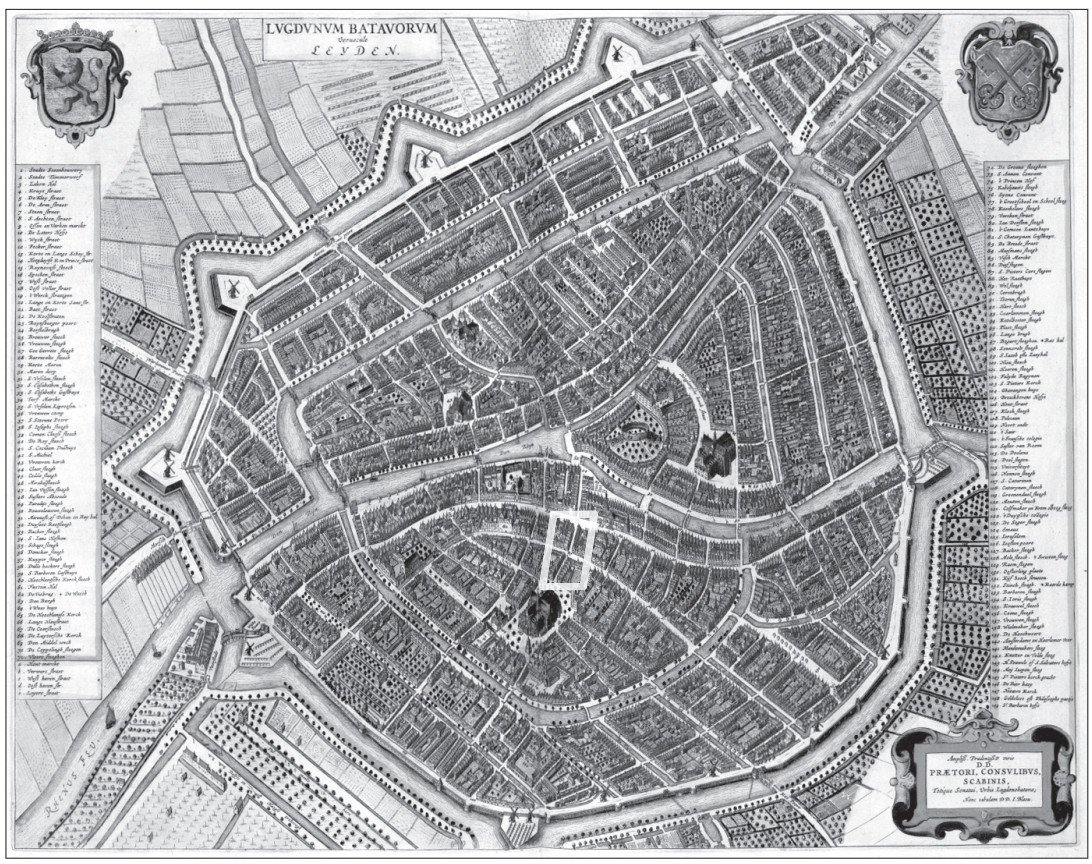

Picture 1. Map of Leiden by Joan Blaeu (1649). Pieterskerk-Choorsteeg street is marked in the center of the map

It reveals not only the previously mentioned points, but also that during his studies in Leiden, Fürecker was staying on S. Pieterschoorsteech street (now Pieterskerk-Choorsteeg, situated between Pieterskerkhof and Langebrug) virtually in the center of Leiden, not far from the Pieterskerk church and from Leiden University (see picture 1). The entry also specifies „in de Moorman“, but it has not yet been possible to determine the exact address of this residence in Pieterskerk-Choorsteeg street.

3. Therefore this gives us hope that in the future we will know more about the biography of Fürecker. In addition, we can also look forward to a study exploring the influence of Fürecker's studies on the thought development at Leiden's Calvinist university, which at the time was experiencing its golden age. But to sum up this article, the most important point to note is that, thanks to the registration records from Leiden University, we now know that Christophor Fürecker was not born in or around 1615, but 1612 . 


\section{Literature}

Album studiosorum $=$

Arbuzovs, Leonīds. 1890.

Arbuzovs, Leonīds. 1925.

Bērziņš, Ludis. 1928.

Bērziņš, Ludis. 1939.

Draviņš̌, Kārlis. 1965.

Frijhoff, Willem. 2008.

Grudule, Māra. 2015.

Grudule, Māra. 2017.

Klekere-Krekele, Ināra. 2001.

Mancelius, Georg. 1633.

Prögler, Daniela. 2016.

Recke, Johann

Friedrich von, Karl Eduard, Napiersky. 1859.

Recke, Johann

Friedrich von, Karl Eduard, Napiersky. 1861.

Rüegg, Walter (ed.). 1992.

Sainio, Matti A. 1978.

Straubergs, Jānis. 1936.
Du Rieu Guilielmus (ed.), Album studiosorum Academiae lugduno batavae MDLXXV-MDCCCLXXV; accedunt nomina curatorum et professorum per eadem secula, Hagae: Comitum apud Martinum Nijhoff, 1875.

Etwas aus alten Stammbücher. Rigascher Almanach für 1891. Riga: W. F. Häcker. 26-44.

17. g. s. latviešu gramatika bij. Kurzemes hercogu bibliotekā Pēterpilī. Filologu biedrības raksti 5, 106-125.

Kristofors Fürekers un viņa nozīme latviešu literatūrā. Filologu biedrības raksti 8, 145-224.

Ernsts Gliks tulkotāja darbā. Izglītības Ministrijas Mēnešraksts 2, 149-161.

Christophor Füreckers, Adolphiis und anderer Anteil an der lettischen Grammatik vom Jahre 1685. Altlettische Schriften und Verfasser 1. Lund. 83-114.

Baltic students in the early modern period. History of Universities 23(2), 174-184.

Kurzemes dzejnieks Kristofors Fīrekers: dzīve un dziesmas, Māras Grudules apcerētas un sakārtotas. [Rīga]: LU Akadēmiskais apgāds.

Latviešu dzejas sākotne 16. un 17. gadsimtā kultūrvēsturiskos kontekstos. Rīga: Latvijas Universitātes Literatūras, folkloras un mākslas institūts.

Latviešu dzejas publikācijas un vienotas literārās telpas veidošanās: 1789-1855. Promocijas darbs. Rìga.

Palaestra theologica privatis XV. exercitiis olim instituta, nunc verò in Regia Academia Dorpatensi aperta. Praeside Georgio Mancelio, Semgallô SS. th. licentiatô, professore, ad D. Joh. Aedem pastore primariô, circuli Dorpatensis praepositô, nec non judicij ecclesiastici adsessore. Dorpati Livonorum, excudebat Jacobus Pistorius. Dorpat: J. Becker.

English Students at Leiden University, 1575-1650: 'Advancing Your Abilities in Learning and Bettering Your Understanding of the World and State Affairs'. London, New York: Routledge.

Allgemeines Schriftsteller- und Gelehrten-Lexikon der Provinzen Livland, Esthland und Kurland. Nachtrzige und Fortsetzungen 1. Mitau: Steffenhagen und Sohn.

Allgemeines Schriftsteller- und Gelehrten-Lexikon der Provinzen Livland, Esthland und Kurland. Nachtrzige und Fortsetzungen 2. Mitau: Steffenhagen und Sohn.

Universities in Early Modern Europe, 500-1800. Cambridge: Cambridge University Press.

Dissertationen und Orationen der Universität Dorpat 1632-1656. Stockholm: Föreningen för svensk undervisningshistoria.

Latviešu pirmās dziesmu grāmatas. Rīgā: Ramave. 
Tering, Arvo. 1984.

Tering, Arvo. 2018.

Tetsch, Karl Ludwig. 1770.

Zoeteman-van Pelt, Martine. 2011.
Album Academicum der Universität Dorpat (Tartu), 1632-1710. Tallinn: Valgus.

Lexikon der Studenten aus Estland, Livland und Kurland an europäischen Universitäten, 1561-1800. Unter Mitarbeit von Jürgen Beyer. Köln: Böhlau Verlag.

Curländifcher Kirfhen=Gefchichte: von dem 3uftande diefer Provincial $=$ Kirche, bis zum Ableben Gotthards erIten Herzogs zu Curland: nebft der gegenwärtigen äußerlichen kirchlichen Verfallung diefes Herzogthums 3. Riga, Leipzig: Johann Friedrich Hartknoch.

De studentenpopulatie van de Leidse universiteit 1575-1812. 'Een volk op zijn Siams gekleet eenige mylen van Den Haag woonende'. Leiden: Leiden University Press.

Ernesta Kazakenaite

Vilnius University

Universiteto g. 3, Vilnius, Lietuva

e.kazakenaite@gmail.com

KOPSAVILKUMS

\section{Piezīmes par Kristofora Fīrekera studijām Leidenes Universitātē un viṇa dzimšanas datumu}

Ernesta KAZAKĖNAITE்

Šajā rakstā īsi aplūkota pieejamā biogrāfiskā informācija par Kristoforu Fīrekeru un publicēts viņa matrikulas Leidenes Universitātē ieraksts. No tā izriet dažas svarīgas lietas. Pirmkārt, Fīrekers neapšaubāmi studējis Leidenes Universitātē - imatrikulēts 1636. gada 6. oktobrī. Otrkārt, dzīvojis Pieterskerk-Choorsteeg ielā esošajā de Moorman rezidencē, kuras precīza adrese ir vēl noskaidrojama. Treškārt, svarīgākais, - matrikulas ierakstā pieminēts, ka tobrīd Fīrekeram bijuši 24 gadi. No tā var secināt, ka Fīrekers ir dzimis nevis 1615. gadā, bet ap 1612. gadu. 